DOI 10.23947/2414-1143-2021-27-3-44-50

UDC 11:159.937:004

\title{
TRANSFORMATIONAL EFFECTS OF VIRTUAL REALITY
}

\author{
(c) Tamara A. Bondarenko
}

\author{
Don State Technical University, Rostov-on-Don, Russian Federation \\ 2467@mail.ru
}

The concept of virtual reality is reconstructed, which is defined as a symbolic, in fact, objectively and actually existing reality. It is initially set by a person; it is dynamic and actively interacts with the person and society as a whole. Being symbolic in nature, it objectively exists only in the consciousness of a person at the moment of being in it. It is noted that due to these properties, virtual reality acts as a significant factor of influence on a person, which is ambivalent in nature, has both positive (lability, new communicative experience, relaxation, etc.) and negative (psychological discomfort, current stress, dependent behaviour, etc.) consequences. Indicated changes in the self-consciousness of the individual are manifested in socially significant actions for the individual. It is shown that virtual reality can help to reveal the inner world of a person, especially his hidden desires, thoughts, and gravitations. Through it, a person can receive moral support, which in general will increase self-esteem, positively affect the psychological state and ensure confident and effective behaviour. The article points to the relevance of the problems both from the point of view of philosophy and from the point of view of practical significance, especially in the field of psychology and pedagogy. behaviour.

Key words: virtual reality, self-awareness, ambivalence, factor potential of virtual reality, virtual

\section{[T.A. Бондаренко Трансформационные эффекты виртуальной реальности]}

Реконструируется понятие виртуальной реальности, которая определяется как символическая, по сути, объективно и актуально существующая реальность. Она изначально задается человеком, отличается динамичностью и активно взаимодействует с человеком и обществом в целом. Будучи символической по своему характеру, она объективно существует лишь в сознании человека в момент пребывания в ней. Отмечается, что в силу указанных свойств виртуальная реальность выступает значительным фрактором влияния на человека, которое носит амбивалентный характер, имеет свои как положительные (лабильность, новый коммуникативный опыт, релаксация и др.), так и отрицательные последствия (психологический дискомфорт, текущий стресс, зависимое поведение и пр.). Обозначены изменения в рамках самосознания личности, которые проявляются в социально значимых для самой личности поступках. Показано, что виртуальная реальность способна помочь раскрыть внутренний мир человека, особенно его скрытые желания, мысли, тяготения. Её посредством человек может получить моральную поддержку, что в целом повысит самооценку, положительно повлияет на психологическое состояние и обеспечит уверенное и эфрфективное поведение. Статья указывает на актуальность проблематики и с точки зрения фрилософии, и с точки зрения практической значимости, особенно в сфере психологии и педагогики.

Ключевые слова: виртуальная реальность, самосознание личности, амбивалентность, факторный потенциал виртуальной реальности, виртуальное поведение.

Tamara A. Bondarenko - Ph.D. (Advanced Doctorate) in Philosophy, Professor, Don State Technical University, Rostov-on-Don, Russian Federation.

Бондаренко Тамара Алексеевна - доктор философрских наук, профрессор, Донской государственный технический университет, г. Ростов-на-Дону, Российская Федерация.

Virtualistic as a relatively new area of cognition is a new paradigm approach in understanding objects and processes in the context of the all-large-scale spread of virtual reality, primarily in its computer version. In this regard, the idea of virtuality has a role to play in explaining the changes taking place in the person and his mind. The concept of virtuality suggests a new paradigm of thinking, which allows you to analyse, in a single 
plane, realities that belong to different types of knowledge - natural science, humanitarian, technical. This makes it possible to give a comprehensive character to the understanding of the changes typical for the modern personality in the consciousness and behaviour. Some changes or transformations are critical, as the social type of personality is destroyed. But it is difficult to speak about the formation of a new type due to the constancy of these changes and, as a result, the instability of a personal status.

The purpose of this article is to determine the most significant transformations of the personality under the influence of virtual reality. To solve this problem, it is supposed to reconstruct the concept of virtual reality in order to reveal the possibilities and directions of its influence on the person, his consciousness and behaviour and also determine the main forms of manifestation of personal changes.

In modern society, many innovative processes and phenomena of social life are widely represented, since there is a formation of such type of society in which information resources are turned into the most important factor of development, and information technologies penetrate into all spheres of human life. There was a need to understand these processes, postmodernism and synergy are being framed as the main directions of scientific thought of the post-non-classical paradigm, which become the intellectual expression of the information revolution and form a new type of worldview that allows to realize the indicated task. A new image of the world is created: " ... since the second half of the $20^{\text {th }}$ century, science has been methodically building bridges between previously torn fields of knowledge. Moreover, the general process which takes place spontaneously does not come down to the now well-known creation of intermediate disciplines such as physical chemistry, biochemistry or sociology. Recent research has a different specificity: they all proceed from the distinct recognition that objects studied by different fundamental sciences (or the worlds to which they belong) have much in common, similar and that they are useful to consider together within the framework of some single cognitive activity" [4, pp. 132-133]. The theoretical tools are replenished with new concepts that claim to reach the categorical level. One of such concepts that shows its scientific validity is the concept of virtual reality.

Today, the term "virtual" is becoming suitable for discourse within a wide range of topics that reflect almost all aspects of society and human life. A certain environment arises between the man and the world around him, indirectly connecting them. Over time, it becomes a self-sufficient reality, replacing the reality of an objectively existing world. Constantly reproducing virtual reality loses the status of belonging exclusively to the technical sphere. It becomes a "metaphorical, symbolic reality," which is organically woven into the complex system of social communications of the information society [1].

The information breakthrough has already led to dramatic changes in the life of people. Both the production and everyday spheres of human life, based on digital technologies, have largely transformed not only the way of human life, but also the very perception of all the changes that have happened, that is why there is a necessity for their philosophical analysis. In this regard, changing the status of virtual reality in human life turns it into an object of reflection. Although today there are developments in the use of the concept of "virtual reality" in line with a specific scientific direction - virtualistic, it should be emphasized that any branch of knowledge individually limits the cognitive potential of the concept. The need for a philosophical understanding of everything that is happening comes on the agenda. Philosophical reflection of problems related to virtual reality began at the end of the $20^{\text {th }}$ century. At that time, the position expressed by one of the founders of virtualistic N. Nosov, who outlined the scientific task of the direction, is interesting: " ... the development and dissemination of virtual philosophy is necessary, i.e. a special virtual way of understanding and explaining the world" [5, p. 13]. And, as Thomas K. Metzinger notes, it is safe to say that: "There are many new fields of philosophical researches for 
which virtual reality is clearly a central goal, including aesthetic judgment and experience, the philosophy of digital art, the philosophy of technology and the philosophy of media" [10].

In the modern interpretation, virtual reality means a symbolic, in fact, objective and relevant existing reality. It is generated, defined and dynamic and actively interacts with the man and society as a whole. Its properties also include ideality, immersion, which is achieved by simulating the real world, specific spatial and temporal characteristics. However, the author's vision of the content of this concept is based on the inconsistency of its content only to manipulation within the framework of virtual reality, but involves understanding it as a process of constant and deep interaction with society, culture and an individual person [1].

The modern man spends a significant part of his actively used time in virtual reality within the Internet. According to Digital 2020, at the beginning of 2020, more than 4.5 billion people use the Internet, and the audience of social networks has exceeded the mark of 3.8 billion. Almost $60 \%$ of the world's population is already online [9]. Three billion people, about $40 \%$ of the world's population, use online social networks and we spend an average of two hours every day on them, updating our status based on various platforms. This comes down to about half a million Snapchat tweets and photos shared by members every minute [7]. Therefore, the processes of interaction between the man and virtual reality, the influence of virtual reality on his consciousness and behaviour are of interest to scientific and philosophical understanding. For the scientific community, it is obvious that the influence of virtual reality is ambivalent in nature, has both positive and negative consequences. We will touch upon those changes in the consciousness and behaviour of the individual that are essential and largely determine changes in the psychological status and social behaviour of the individual.

Before we consider personal changes, we will touch on the influence of virtual reality on the man as a biological organism. Scientists record the fact that changes taking place in the human body, who constantly and for a long time is in virtual reality, are negative. So, at the University of Waterloo (Canada), the research has found that most people using virtual technologies feel discomfort and physical deterioration, that is, the so-called "cybersickness" appears. Cybersickness is defined as a complex of symptoms of discomfort and general malaise (state of nausea, motion sickness, etc.) caused by the use of virtual technology. The technology is used in playing, training professional skills and clinical rehabilitation. Cybersickness can last several hours after the end of a stay in virtual reality [9]. Such a physiological response leads to a change in the somatic status of a person and, of course, affects the state of consciousness, which leads to changes in human behaviour. Changing the states of a stay in virtual and current reality leads to a certain imbalance in a person's self-perception, some confusion and illogical behaviour.

Philosophical understanding of these problems allows us to note that in the spirit of the postmodern era, such a state of personality is objectively formed, which can be called a state of internal uncertainty, variability, "fluidity." This is due to the specific capabilities of virtual reality to create a multiplicity of worlds in which personality manifests itself. Each of these worlds is organized in its own way: its own norms, symbolic language, communication techniques apply, but each of them is open for restructuring, updating that could satisfy the needs of the individual person being in them. Thus, one of the fundamental properties of virtual reality - interactivity, which determines the indicated state of personality is manifested. However, the need to maintain social activity also requires the individual to preserve the skills of effective social behaviour, which in real practice undergoes changes caused by the influence of virtual reality. In the virtual world of the Internet, behavioural techniques and stereotypes differ from those in the real social world, which entails an unstable state of personality. Thus, the integrity and stability of the 
individual, which had determined the effectiveness of social behaviour before, are violated, which leads to the so-called ego-decay.

Among people, especially young people, there is a tendency to increase negative emotions, such as emotional indifference, lack of empathy, feelings of aggression and rejection, which result in similar forms of behaviour. Thus, studies conducted in the specialized laboratory of Stanford University have shown that the video game process with elements of cruelty is a risk factor for stimulating aggressive behaviour, the accumulation of knowledge about aggression and the emergence of aggressive effects, as well as a decrease in the level of prosocial behaviour, empathy and sensitivity to aggression [6].

The article of Jessica Brown, posted on the site as a part of the BBC Future Internet project, notes that the result of the impact of virtual reality on humans is such negative phenomena as stress, psychological discomfort, bad mood, anxiety, depressive conditions [7]. These positions were supported by studies conducted by scientists at universities in different countries, in particular at the University of California, the University of Pittsburgh, Cornell University (USA), the University of Guelph (Canada), etc.

In the framework of psychological research, it is noted that under the influence of virtual reality, due to its ability to form a sense of "immersion," a new problem arises, that is an attachment to screens, i.e. the formation of a dependent type of behaviour. Back in 2011, 43 studies on this issue were analysed at Nottingham Trent University in the UK and it was concluded that dependence on social networks is a mental health problem that may require professional treatment. Overuse of networks was found to be associated with relationship problems, worse academic achievements, and less involvement in offline communities [6, 7].

The vitality of virtual reality creates all the conditions for the emergence of addictive behaviour and the resulting phobias. According to L.Sh. Krupennikova and V.I. Kurbatov there is nomophobia among the most common and directly related to being in a virtual environment, that is a fear of the absence of a mobile device and being out of the network. Those experiencing this phobia have to constantly check the received messages, missed calls, e-mail. Selfie-phobia is a fear of taking a bad photo as a self-presentation and not receiving approval from other Web users. Or, for example, like-phobia is a fear of collecting few likes (approvals) in social networks [3].

Involvement in virtual reality of the Internet due to the fact that it is through it that not only network interpersonal and group communication is carried out, but also a significant part of a person's professional activity leads to behaviour when a person becomes a "permanent controller." A "permanent controller" is a person who continuously, almost obsessively, checks his emails, texts and accounts on social networks [11]. Such form of behaviour acts as both addiction and phobia. All the indicated dependencies and phobias all the more develop the more time the person spends in the virtual environment of the Internet and we can say that addiction and phobias, developing, strengthen each other [2].

In the process of forming a philosophical understanding of virtual reality, the positions of philosophers and sociologists identified themselves, which can be called optimistic. Emphasis was placed on those positive effects which take place as a result of being in virtual reality. Moreover, the restructuring of society in all its spheres through new technologies has always been accompanied by hypertrophied fears primarily about the complexity or obvious negative consequences for a person in the context of such changes. M. Castells, the author of the theory of network society, in particular writes: "As in all moments of major technological changes, people, companies and institutions feel the depth of these changes, but they are often suppressed by them due to a complete misunderstanding of their consequences. Any process of a major technological change gives rise to its own mythology. Partly because it appears in practice before, scientists can assess its essence and consequences, so there is always a gap between social changes 
and their understanding. For example, the media often report that heavy use of the Internet increases the risk of alienation, isolation, depression, and withdrawal from society. In fact, the evidence suggests that there is either no link or a positive cumulative link between Internet use and sociability intensity. We observe that in general, the more sociable people are, the more they use the Internet. And the more they use the Internet the more they increase their communication ability online and offline, their civic activity and the intensity of family and friendship relationships in all cultures" [8]. Moreover, as the author notes that such a turn to the vision of positivity did not immediately arise and Castells reconsidered his position "regarding several early studies of the Internet in the 1990s" in favour of the point of view outlined above.

Virtual reality, acting as an environment external to a man, which is actualized through immersion in it, creates real possibilities for reforming the inner world of a man due to the new experience of finding. Unlike social experience, which is the result of life's successes and failures, the experience of virtual life can be formed purposefully through organizing possible situations and testing several models of behaviour in them with the subsequent selection of the most successful options. A person models not only his behaviour with the subsequent transfer of it to the real life, but also the possible attitude of others to everything that happens, which ultimately leads to changes in the framework of human self-consciousness. Thus, virtual reality contributes to the better understanding of ourselves, our interests and addictions, inclinations and preferences, makes it possible to satisfy the most unusual desires, find like-minded people on various issues, support our own position and, as a result, change the perception of ourselves. So, Jessica Brown, analysing the consequences of using the Facebook Internet platform, writes: "Facebook has had a positive impact on self-esteem compared to other activities that increase selfawareness. Mirrors and photos make us compare ourselves to social standards, while viewing our own Facebook profiles can increase self-esteem, because it is easier to control the way how we are presented to the world" [7].

Virtual practices that realize the capabilities of transformational effects of virtual reality are widely used in a variety of fields: in practical training of professional specialists dealing with complex machines; in practical psychology, psychotherapy and medicine as replaceable and compensating practices. Virtual technologies are increasingly being used in education and science.

It can be concluded that virtual reality significantly affects human consciousness, the process of its formation, the worldview and behaviour, optimizing it or leading to deformations and modifications that entail the emergence of new forms of both virtual and real behaviour of a modern person. The transformational effects of virtual reality are ambiguous. On the one hand, a prolonged stay in virtual reality can form a dependent type of behaviour, phobias, disorders and psychological discomfort. These consequences can be classified as negative transformations of the personal order. On the other hand, the personality becomes more labile, finds new ways of relaxation, acquires additional skills of adaptation and communication, and is less under the pressure of the environment in conditions of dynamic changes in the real social world, that is defined as positive transformations.

Regardless of the nature of transformations, under the influence of virtual reality, new types of socially significant behaviour are formed as a result of changes in the consciousness and self-consciousness of a person, a new view of the world, a new definition of his place in the world. 


\section{Лumepamypa}

1. Бондаренко Т.А. Виртуальная реальность: социально-философрский анализ. Ростов-на-Дону, 2007. 167 с.

2. Бондаренко Т.А. Личностные риски виртуальной среды Интернета // Гуманитарные и социальные науки. 2019. № 6. [Электронный ресурc] URL: http://hses-online.ru/2019_06.html.

3. Крупенникова Л.Ш., Курбатов В.И. Виртуальная личность: Net мышление, сетевой психотип и Интернетфобии // Инженерный вестник Дона. 2014. № 3. [Электронный ресурc] URL: http://ivdon.ru/ru/magazine/archive/n3y2014/2537.

4. Крушанов А.А. Современный образ мира: признаки скрытой виртуализации // Виртуалистика: экзистенциальные и эпистемологические аспекты. М., Прогресс - Традиция, 2007. 384 с.

5. Носов Н.А. Виртуальная психология. М., Аграфр, 2000. 432 с.

6. Bailenson J. Virtual Reality 101: What You Need to Know About Kids and VR. 2018. p.17. [Электронный ресурc] URL:

https://www.commonsensemedia.org/sites/default/files/uploads/research/csm_vr101 final_under5mb.pdf.

7. Brown J. Is social media bad for you? The evidence and the unknowns. 2018. [Электронный ресурc] URL: https://www.bbc.com/future/article/20180104-is-socialmedia-bad-for-you-the-evidence-and-the-unknowns.

8. Castells M. The Impact of the Internet on Society: A Global Perspective. 2014. [Электронный ресурc] URL: https://www.bbvaopenmind.com/en/articles/theimpact-of-the-internet-on-society-a-global-perspective/

9. Health Research News. 2018 [Электронный ресурc] URL: https://www.scitecheuropa.eu/virtual-reality-motion-sickness/89447/

10. Metzinger Thomas K. Why is virtual reality interesting for philosophers? 2018, p. 10. [Электронный ресурc] URL:

https://www.philosophie.fb05.unimainz.de/files/2018/09/Metzinger_VR_Phil_2018_fr obt-05-001mainz.de/files/2018/09/Metzinger_VR_Phil_2018_frobt-05-001

11. Nichols $H$. How modern life affects our physical and mental health. Medical News Today, July3, 2017. [Электронный pecypc] URL: https://www.medicalnewstoday.com/articles/318230

12. Web Canape. Глобальная статистика. [Электронный ресурc] URL: https://www.webcanape.ru/business/internet-2020-globalnaya-statistika-i-trendy/

\section{References}

1. Bondarenko T.A. Virtualnaia realnost: sotsialno-filosofskii analiz [Virtual reality: a socio-philosophical analysis]. Rostov-on-Don, 2007. 167 p. (in Russian).

2. Bondarenko T.A. Lichnostnye riski virtualnoi sredy Interneta. Gumanitarnye i sotsialnye nauki [Personal risks of the virtual environment of the Internet. Humanitarian and Social Sciences]. 2019, No. 6. Available at: http://hsesonline.ru/2019_06.html.

3. Krupennikova L.Sh., Kurbatov V.I. Virtualnaia lichnost: Net myshlenie, setevoi psikhotip i Internetfobii [Virtual identity: Net thinking, psychological type and Internet phobias]. Don's Engineering Gazette, No. 3. 2014. Available at: http://ivdon.ru/ru/magazine/archive/n3y2014/2537.

4. Krushanov A.A. Sovremennyi obraz mira: priznaki skrytoi virtualizatsii. Virtualistika: ekzistentsialnye i epistemologicheskie aspekty [Modern image of the world: signs of 
hidden virtualization. Virtualistic: existential and epistemological aspects]. Moscow, Progress - Traditsiia, 2007. 384 p. (in Russian).

5. Nosov N.A. Virtualnaia psikhologiia [Virtual psychology]. Moscow, Agraf, 2000. 432 p. (in Russian).

6. Bailenson J. Virtual Reality 101: What You Need to Know About Kids and VR. 2018, p.17. Available https://www.commonsensemedia.org/sites/default/files/uploads/research/csm_vr101 final_under5mb.pdf.

7. Brown J. Is social media bad for you? The evidence and the unknowns (2018). Available at: https://www.bbc.com/future/article/20180104-is-social-media-bad-foryou-the-evidence-and-the-unknowns.

8. Castells M. The Impact of the Internet on Society: A Global Perspective (2014). Available at: https://www.bbvaopenmind.com/en/articles/the-impact-of-the-interneton-society-a-global-perspective/

9. Health Research News (2018) Available at: https://www.scitecheuropa.eu/virtualreality-motion-sickness/89447/

10. Metzinger Thomas $K$. Why is virtual reality interesting for philosophers? $(2018$, p. 10). Available at: https://www.philosophie.fb05.unimainz.de/files/2018/09/Metzinger_VR_Phil_2018_fr obt-05-001mainz.de/files/2018/09/Metzinger_VR_Phil_2018_frobt-05-001

11. Nichols $H$. How modern life affects our physical and mental health. Medical News Today, July3, 2017. Available at: https://www.medicalnewstoday.com/articles/318230

12. Web Canape. Global statistics. Available at:

https://www.webcanape.ru/business/internet-2020-globalnaya-statistika-i-trendy/ 